\title{
Chemical Diversity of Volatiles From Parents, Rootstock and Atemoya Hybrid
}

\author{
Felipe Girotto Campos ${ }^{1}$, Maria Aparecida Ribeiro Vieira ${ }^{1}$, Alessandra A. Dos Santos ${ }^{1}$, Letícia Galhardo Jorge ${ }^{1}$, \\ Marcia Ortiz Mayo Marques ${ }^{2} \&$ Carmen Silvia Fernandes Boaro ${ }^{1}$ \\ ${ }^{1}$ Departamento de Botânica, Instituto de Biociências, Universidade Estatual Paulista, Câmpus de Botucatu, \\ Botucatu, São Paulo, Brazil \\ ${ }^{2}$ Centro de Recursos Genéticos Vegetais, Instituto Agronômico, Campinas, São Paulo, Brazil \\ Correspondence: Carmen Silvia Fernandes Boaro, Departamento de Botânica, Instituto de Biociências, \\ Universidade Estatual Paulista, Campus de Botucatu, R. Prof. Dr. Antonio Celso Wagner Zanin, s/n Botucatu, \\ 18618-689, São Paulo, Brazil. Tel: 55-143-880-0124. E-mail: carmen.boaro@unesp.br
}

Received: December 10, 2018

Accepted: January 15, 2019

Online Published: March 15, 2019

doi:10.5539/jas.v11n4p271

URL: https://doi.org/10.5539/jas.v11n4p271

\begin{abstract}
Hybridization promotes the transfer of genetic material from parental species to the hybrid, which can be closely related to one of its parental species or present new features that provide them higher competitivity concerning other chemical phenotype comparing to its parents. On the other hand, grafting technique, in which occurs the combination between two species, also may lead to changes in the volatile profile of terpenes at the grafted plant. The objective of this research was to characterize the chemical profile of volatile compounds in leaves of atemoya hybrid (Annona $\times$ Atemoya) (Mobb.), its male and female parents (Annona squamosa Mill. and Annona cherimola L.), as well as its common rootstock (Annona emarginata (Schltdl.) H. Rainer var. "Terra-fria"). Leaf samples from atemoya, its parents and the rootstock were collected in São Bento do Sapucaí and Santa Fé do Sul, São Paulo state, Brazil. Volatile substances were obtained by microextraction solid phase (SPME). Chemical profile of volatile compounds was determined and identified by gas chromatography coupled to mass spectrometry. Atemoya hybrid presented substances also found in both parents and rootstock, with a variation on the relative percentage of compounds. Such variation allowed to form three clusters, where I was comprised by the hybrid, II comprised by $A$. cherimola, and the latter, III, grouping the rootstock and the male parent. We concluded that hybridization and grafting influence production of terpenes in atemoya hybrid (Annona $\times$ Atemoya).
\end{abstract}

Keywords: Annona $\times$ atemoya, Annona cherimola, Annona squamosa, Annona emarginata, terpenes

\section{Introduction}

Hybridization allows the transfer of genetic material from parental species to the hybrid, which can be more related to one of its parents or show features completely new. Hybrids can present variable adaptation to the local conditions where they occur, which, added to the inherited features from parents, could provide them higher competitivity comparing to the endemic and rare species (López-Caamal \& Tovar-Sánchez, 2014). Though, hybrid phenotype could be typically more robust than that from its parents, resulting in a remarkable importance to agriculture (Greaves et al., 2015).

The Annonaceae family is comprised by the genus Annona, one of its most important, especially due to its edible fruits like those of atemoya (Anonna $\times$ atemoya), a hybrid formed by the outcrossing between Annona cherimola Mill. and Annona squamosa L. Atemoya is characterized by intermediate climatic adaptation in relation to its parents, like fruit quality conferred by $A$. cherimola, as well as the resistance to the climatic conditions conferred by $A$. squamosa (Tokunaga, 2005).

The theme complexity increases, even more, when hybridization is considered together with grafting process. Apparently, the processes of grafting regulation and control occur due to water and mineral nutrients absorption, hormone synthesis, and because of both protein and mRNA migration (Baron, Bravo, Maia, Pina, \& Ferreira, 2016; Davis et al., 2008; Harada, 2010), added to transfer of plastidial DNA from rootstock to the graft (Stegemann \& Bock, 2009). The choose of rootstock species is related to the resistance increase against 
pathogens, faster dissemination and production of fruits, and the ability to impact the graft phenotype, although such mechanisms are not well understood yet (Warschefsky et al., 2016).

Typically, atemoya is grafted in Annona emarginata (Schltdl.) H. Rainer var. 'Terra-fria' which confers diseases and pathogens resistance to hybrid, favoring its cultivation (Baron, Amaro, Pina, \& Ferreira, 2019). Grafting influences the production and chemical profile of volatiles from hybrid essential oils relatively to its parents by the transfer of genetic material and, subsequently, modification in metabolic routes as well as in the specialized metabolism (Cano \& Bermejo, 2011; Harada, 2010).

The production and composition of specialized metabolites could be influenced by the relationship between water availability and transpiration (Santos et al., 2015), phenophase (Herraiz-Peñalver, Ortiz De Elguea-Culebras, Sánchez-Vioque, \& Santana Méridas, 2015), development (De-La-Cruz Chacón, Riley-Saldaña, \& González-Esquinca, 2013), and vegetative organ from where it is extracted (Ceccarini et al., 2004).

Chemical profile of essential oils can variate between parents and hybrid, being that the latter produces higher diversity of substances, (Alzogaray, Lucia, Zerba, \& Masuh, 2011) or present a similar and closer profile concerning to one of its parents (Vereecken, Cozzolino, \& Schiestl, 2010; Zito, Tavella, Sajeva, Carimi, \& Dötterl, 2018). Typically, hybrid shows an intermediate chemical profile from its parents (Herraiz-Peñalver et al., 2015; Ruberto \& Rapisarda, 2002; Zito et al., 2018).

The expression of specialized metabolites is frequently regulated by different genes, which could explain an intermediate chemical volatile profile in hybrids and its parents (Cheng, Vrieling, \& Klinkhamer, 2011; López-Caamal \& Tovar-Sánchez, 2014). Variations in genetic expression of specialized metabolites could be linked to changing of its epigenome (Greaves et al., 2015), indicating an inheritance complex pattern from this trait (Cheng et al., 2011; Zito et al., 2018).

Once insects may be the main allies for several species pollination, as well as in the interaction between plants and defense against herbivores and pathogens (Alzogaray et al., 2011; Hommel et al., 2016; Wang, Liu, Wei, \& Yan, 2012; Zito et al., 2018), the fluctuations in chemical profile could be important for comprehending plant survival strategies, defense and reproduction.

Essential oils present several pharmacological properties (Bakkali, Averbeck, Averbeck, \& Idaomar, 2008; Nakatsu, Lupo, Chinn, \& Kang, 2000), as cytotoxic and abortive effect, immunity suppressing, appetite inhibitor, antiemetic, antimicrobial, pesticide, vermicide, antimalarial and insecticidal (Garavito et al., 2006; Costa et al., 2008; da Silva Almeida et al., 2010; Costa et al., 2011; Langhasova et al., 2014; Sharkey et al., 2017; Hu et al., 2017; Fierascu et al., 2018). These essential oils confer perfumed scents due to its composition, especially, monoterpenes and sesquiterpenes, as bicyclogermacrene, $(E)$-caryophyllene, $\gamma$-muurolene, $\alpha$-humulene, spathulenol, and $\beta$-elemene.

Species from Annonaceae family, including parents, rootstock and hybrids, present essential oils with different substances that, besides acting in defense strategies and pollinators attraction for reproduction and survival, also may show pharmacological properties with economic importance.

The objective of this research was to characterize and compare chemical profile composition of leaf volatiles in hybrid Annona $\times$ atemoya (Mobb.), with its parents Annona cherimola L., Annona squamosa Mill. and the rootstock Annona emarginata (Schltdl.) H. Rainer var. "Terra-fria".

\section{Material and Methods}

\subsection{Study Area}

Leaf samples from hybrid (Annona $\times$ atemoya), female parent (Annona cherimola) and the rootstock (Annona emarginata) were collected at Núcleo de Produção de Mudas da CATI (Coordenadoria de Assistência Técnica e

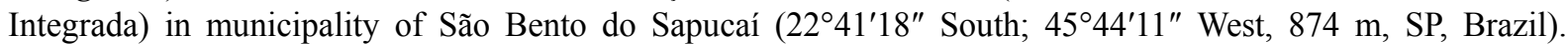
Leaves from male parent (Annona squamosa), species that is usually cultivated in warmer regions, were

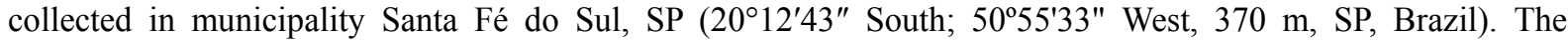
samplings were carried out between 9:00-10:00 hours and stored in paper bags.

\subsection{Capture and Analysis of Volatile Compounds}

Leaves were dried in a forced air oven with a temperature held at $30{ }^{\circ} \mathrm{C}$ to achieve its constant dry mass. Volatile substances were captured by headspace-solid phase microextraction (HS-SPME). So, $50 \mathrm{~mL}$ of leaf dry mass grinded were stored in a $20 \mathrm{~mL}$ glass vial with a cover provided of a septum, and subsequently added $10 \mathrm{~mL}$ of distilled water. The vial glass was heated for 1 hour in a water bath at $90{ }^{\circ} \mathrm{C}$. Afterward, the volatile compounds 
were captured by headspace for 15 minutes using a DVB/PDMS fiber (Manual Holder-SUPELCO). The extraction of volatile compounds was executed in triplicate for each sample.

Chemical analysis of volatile compounds was determined by gas chromatograph coupled to a mass spectrometer (GC-MS-Shimadzu, QP-5000), operating at $70 \mathrm{eV}$, equipped with a DB-5 fused silica capillary column $(30 \mathrm{~m} \times$ $0.25 \mathrm{~mm} \times 0.25 \mu \mathrm{m})$, helium as carrier gas $(1.0 \mathrm{~mL} / \mathrm{min})$, injector at $240{ }^{\circ} \mathrm{C}$, detector at $230^{\circ} \mathrm{C}$, split: $1 / 20$, using the temperature program of $60-240{ }^{\circ} \mathrm{C}, 3{ }^{\circ} \mathrm{C} / \mathrm{min}$.

Substances were identified by comparing its mass spectrum with data bank from CG-EM (Nist 62.lib) system; Retention indexes (IR) and literature data (Adams, 2017). Retention indexes (IR) of the substances were obtained by analysis of the mixture of n-alkanes $\left(\mathrm{C}_{9}-\mathrm{C}_{24}\right.$ Sigma Aldrich $\left.99 \%\right)$, at the same operational conditions of samples, in which it was applied the equation of Van den Dool \& Kratz, 1963 (Van Den Dool \& Dec. Kratz, 1963).

\subsection{Statistical Analysis}

Principal component analysis (PCA) and Hierarchical agglomerative cluster (HAC) (algorithm UPGMA, similarity index, Pearson correlation coefficient) were carried out with relative percentages of identified substances (software XLSTAT v.2017 ADDINSOFT®, 2017).

\section{Results}

In this study were identified fifty volatile substances, distributed in mono and sesquiterpenes, from parents, rootstock, and hybrid. Among them, $85.93 \%$ were verified in A. cherimola, $94.60 \%$ in A. squamosa, $96.40 \%$ in $A$. emarginata and $94.02 \%$ in atemoya (Annona $\times$ atemoya) (Table 1).

Table 1. Mean chemical composition (relative percentage) from the components in atemoya hybrid (Annona $\times$ atemoya), its female parent (Annona cherimola), male parent (Annona squamosa), and rootstock (Annona emarginata)

\begin{tabular}{|c|c|c|c|c|c|c|}
\hline Substances & $\mathrm{IR}_{\mathrm{E}}$ & $\mathrm{IR}_{\mathrm{L}}$ & $\begin{array}{l}\text { Annona } \\
\text { cherimola } \bigcirc\end{array}$ & $\begin{array}{l}\text { Annona } \\
\text { squamosa } \widehat{\widehat{O}}\end{array}$ & $\begin{array}{l}\text { Annona emarginata } \\
\text { (rootstock) }\end{array}$ & $\begin{array}{l}\text { Annona } \times \text { atemoya } \\
\text { (hybrid) }\end{array}$ \\
\hline \multicolumn{7}{|c|}{ Monoterpene Hydrocarbons } \\
\hline Tricyclene & 924 & 926 & $\mathrm{t}$ & $\mathrm{t}$ & 0.56 & 0.54 \\
\hline$\alpha$-Pinene & 931 & 939 & 11.62 & 3.52 & 10.07 & 17.76 \\
\hline Camphene & 946 & 954 & 2.10 & 9.08 & 3.51 & 0.82 \\
\hline Sabinene & 973 & 975 & 0.01 & 0.24 & 0.37 & 0.63 \\
\hline$\beta$-Pinene & 975 & 979 & 16.99 & 3.18 & 6.29 & 11.43 \\
\hline Myrcene & 989 & 990 & 0.84 & 2.33 & 4.73 & 7.39 \\
\hline$\delta$-3-Carene & 1004 & 1011 & 0.66 & $\mathrm{t}$ & $\mathrm{t}$ & 0.88 \\
\hline$\alpha$-Terpinene & 1020 & 1017 & 0.01 & $\mathrm{t}$ & $\mathrm{t}$ & 0.74 \\
\hline$\rho$-Cymene & 1023 & 1024 & 5.16 & $\mathrm{t}$ & 1.28 & 3.22 \\
\hline Limonene & 1027 & 1029 & 2.45 & 2.77 & 13.08 & 15.51 \\
\hline (Z)- $\beta$-Ocimene & 1035 & 1037 & $\mathrm{t}$ & $\mathrm{t}$ & $\mathrm{t}$ & 0.60 \\
\hline (E)- $\beta$-Ocimene & 1045 & 1050 & $\mathrm{t}$ & $\mathrm{t}$ & $\mathrm{t}$ & 0.92 \\
\hline$\gamma$-Terpinene & 1057 & 1059 & 0.59 & $\mathrm{t}$ & 0.45 & 0.96 \\
\hline Terpinolene & 1087 & 1088 & 0.01 & $\mathrm{t}$ & $\mathrm{t}$ & 0.66 \\
\hline$m$-Cymenene & 1087 & 1085 & 1.06 & $\mathrm{t}$ & 0.73 & $\mathrm{t}$ \\
\hline \multicolumn{7}{|c|}{ Oxygenated Monoterpenes } \\
\hline 1,8-Cineole & 1029 & 1031 & 0.99 & $\mathrm{t}$ & 4.23 & 0.01 \\
\hline Linalool & 1099 & 1096 & 9.63 & $\mathrm{t}$ & 0.43 & 2.23 \\
\hline$\alpha$-Campholenal & 1124 & 1126 & 1.79 & $\mathrm{t}$ & $\mathrm{t}$ & $\mathrm{t}$ \\
\hline Pinocarvone & 1159 & 1164 & 3.77 & $\mathrm{t}$ & $\mathrm{t}$ & $\mathrm{t}$ \\
\hline Myrtenol & 1193 & 1195 & 5.17 & $\mathrm{t}$ & $\mathrm{t}$ & $\mathrm{t}$ \\
\hline \multicolumn{7}{|c|}{ Sesquiterpene Hydrocarbons } \\
\hline$\delta$-Elemene & 1333 & 1338 & 1.81 & 5.59 & $\mathrm{t}$ & 0.52 \\
\hline$\alpha$-Cubebene & 1345 & 1348 & $\mathrm{t}$ & $\mathrm{t}$ & 0.49 & 0.09 \\
\hline$\alpha$-Copaene & 1372 & 1376 & $\mathrm{t}$ & 0.25 & 0.72 & 0.55 \\
\hline$\beta$-Bourbonene & 1381 & 1388 & $\mathrm{t}$ & 0.27 & 1.28 & 0.88 \\
\hline$\beta$-Elemene & 1392 & 1390 & 1.88 & 5.54 & 0.59 & 1.37 \\
\hline
\end{tabular}




\begin{tabular}{|c|c|c|c|c|c|c|}
\hline Sesquithujene & 1402 & 1405 & $\mathrm{t}$ & $\mathrm{t}$ & 0.43 & $\mathrm{t}$ \\
\hline trans-Caryophyllene & 1415 & 1419 & 1.85 & 35.82 & 20.50 & 2.59 \\
\hline$\beta$-Copaene & 1425 & 1432 & $\mathrm{t}$ & 0.25 & 0.67 & 0.09 \\
\hline Aromadendrene & 1434 & 1441 & $\mathrm{t}$ & 0.17 & 0.90 & 0.09 \\
\hline$\alpha$-Humulene & 1449 & 1454 & $\mathrm{t}$ & 4.80 & 1.86 & 0.53 \\
\hline allo-Aromadendrene & 1456 & 1460 & $\mathrm{t}$ & 0.38 & 0.81 & 0.42 \\
\hline cis-Muurola-4(14),5-diene & 1458 & 1466 & $\mathrm{t}$ & 0.29 & $\mathrm{t}$ & 0.13 \\
\hline$\gamma$-Muurolene & 1471 & 1479 & $\mathrm{t}$ & 0.72 & 0.88 & 0.35 \\
\hline$\gamma$-Gurjunene & 1477 & 1477 & 4.09 & 4.92 & 2.07 & 9.11 \\
\hline ar-Curcumene & 1478 & 1480 & $\mathrm{t}$ & $\mathrm{t}$ & 10.27 & $\mathrm{t}$ \\
\hline Germacrene D & 1486 & 1481 & 0.50 & 0.40 & 0.01 & 0.26 \\
\hline$\delta$-Selinene & 1491 & 1492 & 0.74 & 6.76 & 4.84 & 8.12 \\
\hline$\alpha$-Muurolene & 1495 & 1500 & $\mathrm{t}$ & 0.71 & 0.27 & 0.27 \\
\hline$\beta$-Bisabolene & 1499 & 1505 & $\mathrm{t}$ & 2.11 & 0.01 & 0.44 \\
\hline$\gamma$-Cadinene & 1508 & 1513 & $\mathrm{t}$ & 2.35 & 0.56 & 0.44 \\
\hline \multicolumn{7}{|l|}{ Oxygenated Sesquiterpenes } \\
\hline Cubebol & 1517 & 1515 & 0.91 & 1.56 & 2.78 & 0.63 \\
\hline Spathulenol & 1577 & 1578 & 0.70 & $\mathrm{t}$ & 0.28 & 0.45 \\
\hline Caryophyllene oxide & 1582 & 1583 & 2.18 & $\mathrm{t}$ & $\mathrm{t}$ & $\mathrm{t}$ \\
\hline Cubenol & 1640 & 1646 & $\mathrm{t}$ & 0.33 & $\mathrm{t}$ & $\mathrm{t}$ \\
\hline \multicolumn{7}{|l|}{ Other classes } \\
\hline 6-methyl-5-hepten-2-one & 983 & 985 & 1.00 & $\mathrm{t}$ & $\mathrm{t}$ & $\mathrm{t}$ \\
\hline$n$-Decane & 999 & 1000 & 0.21 & $\mathrm{t}$ & $\mathrm{t}$ & $\mathrm{t}$ \\
\hline 2-Nonanone & 1090 & 1090 & 5.53 & $\mathrm{t}$ & $\mathrm{t}$ & 1.99 \\
\hline$n$-Nonanal & 1102 & 1100 & 1.29 & $\mathrm{t}$ & 0.30 & t \\
\hline 2-Decanone & 1190 & 1192 & 0.01 & $\mathrm{t}$ & $\mathrm{t}$ & 0.29 \\
\hline$n$-Decanal & 1203 & 1201 & 0.21 & $\mathrm{t}$ & $\mathrm{t}$ & $\mathrm{t}$ \\
\hline Total identified & & & 85.93 & 94.60 & 96.40 & 94.02 \\
\hline Monoterpene Hydrocarbons & & & 41.52 & 21.21 & 41.12 & 62.05 \\
\hline Oxygenated Monoterpenes & & & 21.35 & 0.05 & 4.69 & 2.27 \\
\hline Sesquiterpene Hydrocarbons & & & 11.01 & 71.36 & 47.16 & 26.27 \\
\hline Oxygenated Sesquiterpenes & & & 3.81 & 1.92 & 3.08 & 1.10 \\
\hline Other classes & & & 8.25 & 0.06 & 0.35 & 2.32 \\
\hline
\end{tabular}

Note. $\mathrm{IR}_{\mathrm{E}}=$ retention index experimental; $\mathrm{IR}_{\mathrm{L}}=$ retention index literature (Adams, 2007); $\mathrm{t} \leq 0.2$.

Female parent and hybrid presented major relative percentages of monoterpenes $(62.86 \%$ and $64.32 \%$; respectively). The male parent presented major relative percentages of sesquiterpenes $(73.28 \%)$, and the rootstock showed similar relative percentages of mono and sesquiterpenes (45.81\% and 50.24\%; respectively). Among mono and sesquiterpenes, Annona cherimola, female parent, the predominant substances were $\alpha$-pinene (11.62\%), $\beta$-pinene $(16.99 \%)$ and linalool $(9.63 \%)$. Major substances in A. squamosa, male parent, were trans-caryophyllene (35.82\%), camphene $(9.08 \%)$ and $\delta$-selinene $(6.76 \%)$. Volatile compounds from rootstock, $A$. emarginata, were predominantly $\alpha$-pinene $(10.07 \%), \beta$-pinene $(6.29 \%)$, limonene $(13.08 \%)$, trans-caryophyllene $(20.50 \%)$ and ar-curcumene (10.27\%). Major substances in atemoya hybrid were $\alpha$-pinene $(17.76 \%)$, $\beta$-pinene $(11.43 \%)$, limonene $(15.51 \%), \gamma$-gurjunene $(9.11 \%), \delta$-selinene $(8.12 \%)$ (Table 1$)$.

Principal component analysis with the identified substances indicates that A. emarginata and A. squamosa have chemical profile discriminated by trans-caryophyllene, while atemoya hybrid (Annona $\times$ atemoya) is discriminated by $\alpha$ and $\beta$-pinene, and at last, A. cherimola is discriminated by $\alpha$ and $\beta$-pinene, $p$-cymene, 2-nonanone, linalool and $\gamma$-gurjunene (Figure 1).

The dendrogram presents the formation of three clusters, in which cluster I is comprised by atemoya hybrid, cluster II by $A$. cherimola and, III groups the rootstock $A$. emarginata and male parent $A$. squamosa (Figure 2). 


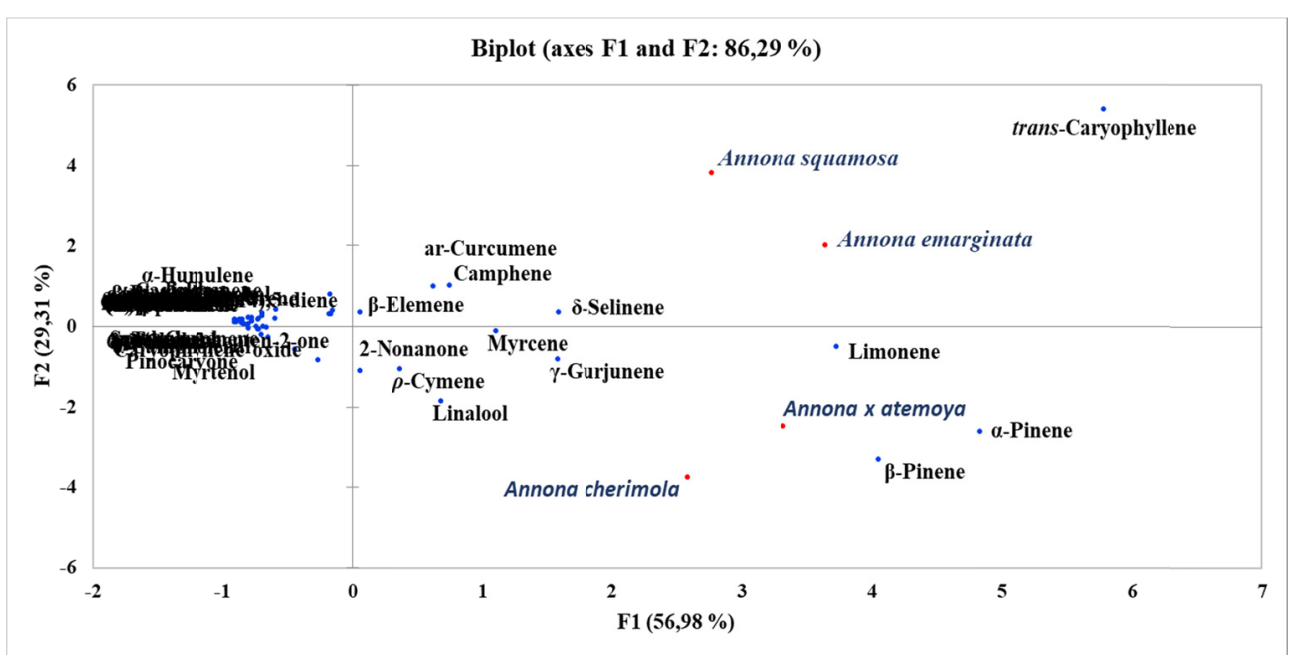

Figure 1. Principal component analysis (PCA) with chemical profile of volatiles substances from atemoya hybrid $($ Annona $\times$ atemoya), its female parent (Annona cherimola), male parent (Annona squamosa), and its rootstock

\section{(Annona emarginata)}

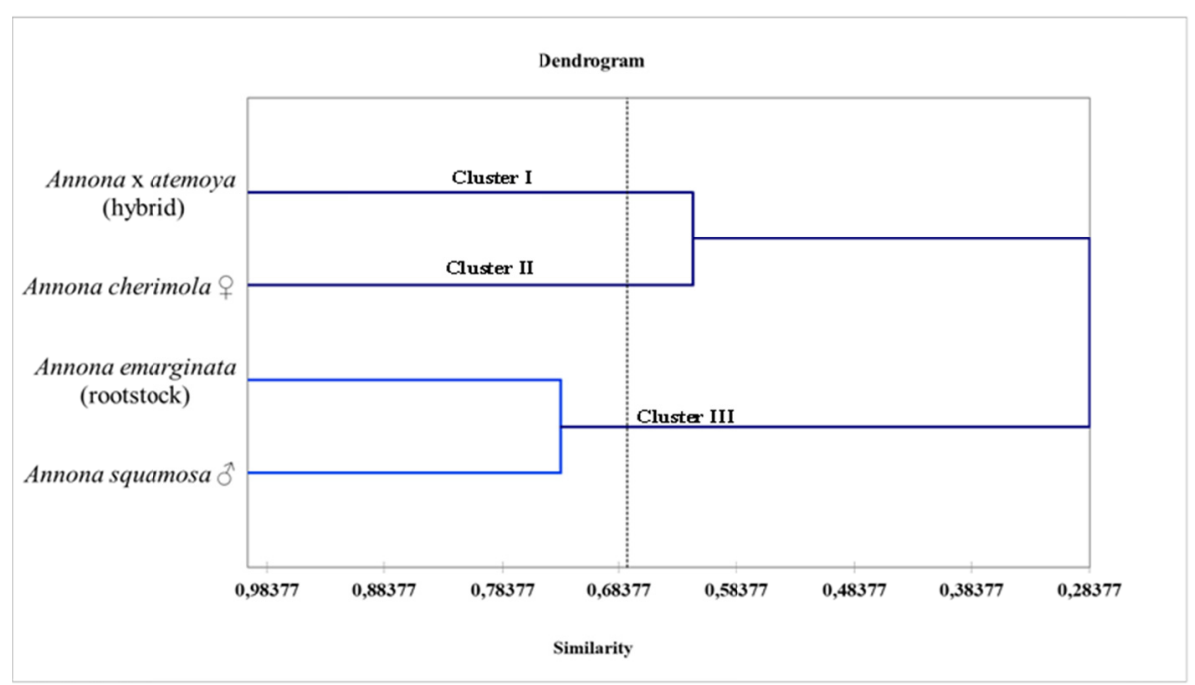

Figure 2. Dendrogram achieved by hierarchical agglomerative clustering analysis (HAC) with volatile substances from atemoya hybrid (Annona $\times$ atemoya), its female parent (Annona cherimola), male parent (Annona squamosa), and rootstock (Annona emarginata)

\section{Discussion}

Chemical profile of volatile compounds achieved demonstrated that there is a clear relationship between these substances found in female parent (Annona cherimola), male parent (A. squamosa), rootstock (A. emarginata) and those ones present in atemoya hybrid (Annona $\times$ atemoya).

Our results indicate that the hybrid (Annona $\times$ atemoya) have intermediate volatile substances also present in its parents, according to the also found in the literature (Cheng et al., 2011). However, this hybrid has similar substances with those that occur in the rootstock $(A$. emarginata). It must be remarked that this is the first result demonstrating this kind of relationship between hybrid (Annona $\times$ atemoya) and rootstock (A. emarginata) (Campos et al., 2019), which constitute part of a major study of our research group.

The dendrogram and PCA showed a similarity between rootstock (A. emarginata) and male parent ( $A$. squamosa). In the same way, it was denoted a similarity between hybrid (Annona $\times$ atemoya) and its female parent (Annona cherimola). Hence, substances present in chemical profile of hybrid could be expressed as a result of genetic material transfer from both parents and rootstock, which suggest once again, that the 
compatibility and success in hybrid grafting frequently occur due to similar features between rootstock and at least one its parents, according to the already recorded by Baron et al. (2019), condition that may be suggested by this present work about chemical profile of volatiles.

According to the interpretation of Cheng et al. (2011), the studied chemical profiles of volatiles reveal that atemoya hybrid (Annona $\times$ atemoya) expressed intermediate phenotype in relation to its parents. However, our results reveal that atemoya also present a chemical profile intermediate to the rootstock. These results are in agreement with studies in literature, which report that the majority of specialized metabolites can be expressed in similar concentrations or even intermediate to those ones from its parents (Zito et al., 2018). Besides, in hybrid, substances may have its relative percentages raised or even suppressed (Cheng et al., 2011; López-Caamal \& Tovar-Sánchez, 2014), condition that can contribute with the intermediate chemical profile.

Although it was not possible to identify and confirm the origin of substances presented in hybrid from its parents and rootstock, hybridization and grafting associated to both environment and intraspecific conditions, may contribute to variations in the expression of the volatile profile (Selmar \& Kleinwächter, 2013; Zito et al., 2018). This variation can provide greater resistance to pathogens, allowing a better environment adaptation in different climatic conditions (Baron et al., 2019; Chezem \& Clay, 2016).

Predominant substances responsible by discriminating the volatile profile of female parent (Annona cherimola), male parent ( $A$. squamosa), rootstock (A. emarginata), and the hybrid (Annona $\times$ atemoya), suggest the expression of important volatiles for each one, which can be tightly related to plant defense (Alzogaray et al., 2011; Brophy, Forster, Goldsack, Hibbert, \& Punruckvong, 2009; López-Caamal \& Tovar-Sánchez, 2014; Zito et al., 2018), such as trans-caryophyllene, limonene, p-cymene, $\alpha$ and $\beta$-pinene, substances to have bactericidal activity (Marchese et al., 2017; Perigo et al., 2016; Ríos, Castrejón, Robledo, León, \& Rojas, 2003) and may have contributed to the hybrid plant defense.

Despite the variation in relative percentage and substances predominance of volatile profile from both parents and rootstock, these plants show similar substances, which suggest that hybridization and grafting influence terpene production in atemoya hybrid.

\section{References}

Adams, R. P. (2017). Identification of Essential Oil Components by Gas Chromatography (4.1 ed.). Allured Pub Corp.

Alzogaray, R. A., Lucia, A., Zerba, E. N., \& Masuh, H. M. (2011). Insecticidal Activity of Essential Oils From Eleven Eucalyptus spp. and Two Hybrids: Lethal and Sublethal Effects of Their Major Components on Blattella germanica. Journal of Economic Entomology, 104(2), 595-600. https://doi.org/10.1603/EC10045

Bakkali, F., Averbeck, S., Averbeck, D., \& Idaomar, M. (2008). Biological effects of essential oils-A review. Food and Chemical Toxicology, 46(2), 446-475. https://doi.org/10.1016/j.fct.2007.09.106

Baron, D., Amaro, A. C. E., Pina, A., \& Ferreira, G. (2019). An overview of grafting re-establishment in woody fruit species. Scientia Horticulturae, 243, 84-91. https://doi.org/10.1016/j.scienta.2018.08.012

Baron, D., Bravo, J. P., Maia, I. G., Pina, A., \& Ferreira, G. (2016). UGP gene expression and UDP-glucose pyrophosphorylase enzymatic activity in grafting annonaceous plants. Acta Physiologiae Plantarum, 38(3), 79. https://doi.org/10.1007/s11738-016-2097-7

Brophy, J. J., Forster, P. I., Goldsack, R. J., Hibbert, D. B., \& Punruckvong, A. (2009). (Myrtaceae) and their hybrids. Australian Journal of Botany, 57(5), 425. https://doi.org/10.1071/BT08171

Cano, A., \& Bermejo, A. (2011). Influence of rootstock and cultivar on bioactive compounds in citrus peels. Journal of the Science of Food and Agriculture, 91(9), 1702-1711. https://doi.org/10.1002/jsfa.4375

Ceccarini, L., Macchia, M., Flamini, G., Cioni, P. L., Caponi, C., \& Morelli, I. (2004). Essential oil composition of Helianthus annuus L. leaves and heads of two cultivated hybrids "Carlos" and "Florom 350" Industrial Crops and Products, 19, 13-17. https://doi.org/10.1016/S0926-6690(03)00076-1

Cheng, D., Vrieling, K., \& Klinkhamer, P. G. L. (2011). The effect of hybridization on secondary metabolites and herbivore resistance: Implications for the evolution of chemical diversity in plants. Phytochemistry Reviews: Proceedings of the Phytochemical Society of Europe, 10(1), 107-117. https://doi.org/10.1007/s11101 $-010-9194-9$

Chezem, W. R., \& Clay, N. K. (2016). Regulation of plant secondary metabolism and associated specialized cell development by MYBs and bHLHs. Phytochemistry, 131, 26-43. https://doi.org/10.1016/J.PHYTOCHEM. 


\subsubsection{6}

Costa, E. V., Dutra, L. M., Jesus, H. C. R. de, Nogueira, P. C. de L., Moraes, V. R. de S., Salvador, M. J., ... Prata, A. P. do N. (2011). Chemical Composition and Antioxidant, Antimicrobial, and Larvicidal Activities of the essential Oils of Annona salzmannii and A. pickelii (Annonaceae). Natural Product Communications, 6(6), 907-912. https://doi.org/10.1073/pnas.0703993104

Costa, M. da S., Pereira, M. J. B., Oliveira, S. S. de, Souza, P. T. de, Dall'oglio, E. L., \& Alves, T. C. (2013). Anonáceas provocam mortalidade em larvas de Aedes aegypti (Linnaeus, 1762) (Diptera: Culicidae). Revista Brasileira de Biociências, 11(2), 184-190.

Costa, V. C. O., Tavares, J. F., Agra, M. F., Falcão-Silva, V. S., Facanali, R., Vieira, M. A. R., ... Da Silva, M. S. (2008). Composição química e modulação da resistência bacteriana a drogas do óleo essencial das folhas de Rollinia leptopetala R. E. Fries. Brazilian Journal of Pharmacognosy. https://doi.org/10.1590/S0102-695X 2008000200019

da Silva Almeida, J. R. G., Facanali, R., Vieira, M. A. R., Marques, M. O. M., Lúcio, A. S. S. C., de Oliveira Lima, E., ... Barbosa-Filho, J. M. (2010). Composition and Antimicrobial Activity of the Leaf Essential Oils of Duguetia gardneriana Mart. and Duguetia moricandiana Mart. (Annonaceae). Journal of Essential Oil Research, 22(3), 275-278. https://doi.org/10.1080/10412905.2010.9700323

Davis, A. R., Perkins-Veazie, P., Hassell, R., Levi, A., King, S. R., \& Zhang, X. (2008). Grafting effects on vegetable quality. HortScience, 43(6), 1670-1672. https://doi.org/10.1111/j.1365-2672.2005.02634.X

De-La-Cruz Chacón, I., Riley-Saldaña, C. A., \& González-Esquinca, A. R. (2013). Secondary metabolites during early development in plants. Phytochemistry Reviews, 12(1), 47-64. https://doi.org/10.1007/s11101-0129250-8

Fierascu, I., Dinu-Pirvu, C. E., Fierascu, R. C., Velescu, B. S., Anuta, V., Ortan, A., \& Jinga, V. (2018). Phytochemical Profile and Biological Activities of Satureja hortensis L.: A Review of the Last Decade. Molecules, 23(10), 2458. https://doi.org/10.3390/molecules23102458

Garavito, G., Rincón, J., Arteaga, L., Hata, Y., Bourdy, G., Gimenez, A., ... Deharo, E. (2006). Antimalarial activity of some Colombian medicinal plants. Journal of Ethnopharmacology, 107(3), 460-462. https://doi.org/10.1016/j.jep.2006.03.033

Greaves, I. K., Gonzalez-Bayon, R., Wang, L., Zhu, A., Liu, P.-C., Groszmann, M., ... Dennis, E. S. (2015). Epigenetic Changes in Hybrids. Plant Physiology, 168(4), 1197-1205. https://doi.org/10.1104/pp.15.00231

Harada, T. (2010). Grafting and RNA transport via phloem tissue in horticultural plants. Scientia Horticulturae, 125(4), 545-550. https://doi.org/10.1016/j.scienta.2010.05.013

Herraiz-Peñalver, D., Ortiz De Elguea-Culebras, G., Sánchez-Vioque, R., \& Santana Méridas, O. (2015). Identification of a hybrid species of sage (Salvia officinalis L. $\times$ S. lavandulifolia subsp. lavandulifolia) through the study of the essential oil. Journal of Essential Oil Research, 27(5), 363-372. https://doi.org/ 10.1080/10412905.2015.1031918

Hommel, R., Siegwolf, R., Zavadlav, S., Arend, M., Schaub, M., Galiano, L., ... Gessler, A. (2016). Impact of interspecific competition and drought on the allocation of new assimilates in trees. Plant Biology. https://doi.org/10.1111/plb.12461

Hu, Y., Zhang, J., Kong, W., Zhao, G., \& Yang, M. (2017). Mechanisms of antifungal and anti-aflatoxigenic properties of essential oil derived from turmeric (Curcuma longa L.) on Aspergillus flavus. Food Chemistry. https://doi.org/10.1016/j.foodchem.2016.09.179

Langhasova, L., Hanusova, V., Rezek, J., Stohanslova, B., Ambroz, M., Kralova, V., ... Skalova, L. (2014). Essential oil from Myrica rubra leaves inhibits cancer cell proliferation and induces apoptosis in several human intestinal lines. Industrial Crops and Products, 59. https://doi.org/10.1016/j.indcrop.2014.04.018

López-Caamal, A., \& Tovar-Sánchez, E. (2014). Genetic, morphological, and chemical patterns of plant hybridization. https://doi.org/10.1186/s40693-014-0016-0

Marchese, A., Arciola, C. R., Barbieri, R., Silva, A. S., Nabavi, S. F., Sokeng, A. J. T., ... Nabavi, S. M. (2017). Update on monoterpenes as antimicrobial agents: A particular focus on p-cymene. Materials, 10(8), 1-15. https://doi.org/10.3390/ma10080947

Nakatsu, T., Lupo, A. T., Chinn, J. W., \& Kang, R. K. L. (2000). Biological activity of essential oils and their constituents. Studies in Natural Products Chemistry, 21(Part B), 571-631. https://doi.org/10.1016/ 


\section{S1572-5995(00)80014-9}

Perigo, C. V., Torres, R. B., Bernacci, L. C., Guimarães, E. F., Haber, L. L., Facanali, R., ... Marques, M. O. M. (2016). The chemical composition and antibacterial activity of eleven Piper species from distinct rainforest areas in Southeastern Brazil. Industrial Crops and Products, 94, 528-539. https://doi.org/10.1016/j.indcrop. 2016.09.028

Ríos, M. Y., Castrejón, F., Robledo, N., León, I., \& Rojas, G. (2003). Chemical Composition and Antimicrobial Activity of the Essential Chemical Composition and Antimicrobial Activity of the Essential Oils from Annona cherimola (Annonaceae). J. Mex. Chem. Soc., 47, 139-142.

Ruberto, G., \& Rapisarda, P. (2002). Essential oils of new pigmented citrus hybrids: Citrus sinensis L. Osbeck $\times$ C. clementina Hort. ex Tanaka. Journal of Food Science, 67(7), 2778-2780. https://doi.org/10.1111/ j.1365-2621.2002.tb08815.x

Santos, J. Z., Almeida, L. A. H., Soares Filho, W. S., Bizzo, H. R., Santos, M. C. D. S., Mattos, J. K. A., ... Vieira, R. F. (2015). Chemical characterization of the essential oils from leaves of mandarins Sunki, Cleopatra and their hybrids. Journal of Essential Oil Research, 27(1), 1-8. https://doi.org/10.1080/ 10412905.2014.973067

Selmar, D., \& Kleinwächter, M. (2013). Influencing the product quality by deliberately applying drought stress during the cultivation of medicinal plants. Industrial Crops and Products, 42(1), 558-566. https://doi.org/ 10.1016/j.indcrop.2012.06.020

Sharkey, C. C., Li, J., Roy, S., Wu, Q., King, M. R., Nandakumar, N., .. Pacak, K. (2017). Hypoxia potentiates the cytotoxic effect of piperlongumine in pheochromocytoma models. European Journal of Medicinal Chemistry, 7(1), 2-6. https://doi.org/10.1016/j.ejmech.2015.10.052

Stegemann, S., \& Bock, R. (2009). Exchange of Genetic Material Between Cells in Plant Tissue Grafts. Science, 324(5927), 649-651. https://doi.org/10.1126/science.1170397

Tokunaga, T. (2005). The atemoya cultivation (CATI ed.). Campinas: Boletim técnico.

Van Den Dool, H., \& Dec. Kratz, P. (1963). A generalization of the retention index system including linear temperature programmed gas-liquid partition chromatography. Journal of Chromatography A, 11(3), 463-471. https://doi.org/10.1016/S0021-9673(01)80947-X

Vereecken, N. J., Cozzolino, S., \& Schiestl, F. P. (2010). Hybrid floral scent novelty drives pollinator shift in sexually deceptive orchids. BMC Evolutionary Biology, 10(1), 103. https://doi.org/10.1186/1471-2148$10-103$

Wang, H., Liu, Y., Wei, S., \& Yan, Z. (2012). Comparative seasonal variation and chemical composition of essential oils from the leaves and stems of Schefflera heptaphylla using microwave-assisted and conventional hydrodistillation. Industrial Crops and Products, 36(1), 229-237. https://doi.org/10.1016/ j.indcrop.2011.09.011

Warschefsky, E. J., Klein, L. L., Frank, M. H., Chitwood, D. H., Londo, J. P., Von Wettberg, E. J. B., \& Miller, A. J. (2016). Rootstocks: Diversity, Domestication, and Impacts on Shoot Phenotypes. https://doi.org/10.1016/ j.tplants.2015.11.008

Zito, P., Tavella, F., Sajeva, M., Carimi, F., \& Dötterl, S. (2018). Inflorescence Scents of Calendula maritima, Calendula suffruticosa subsp. fulgida, and Their Hybrid. International Journal of Plant Sciences, 179(5), 415-421. https://doi.org/10.1086/697240

\section{Copyrights}

Copyright for this article is retained by the author(s), with first publication rights granted to the journal.

This is an open-access article distributed under the terms and conditions of the Creative Commons Attribution license (http://creativecommons.org/licenses/by/4.0/). 